\title{
ОКРЕМІ АСПЕКТИ ВНЕСЕННЯ МАЙНОВИХ ПРАВ ІНТЕЛЕКТУАЛЬНОӤ ВЛАСНОСТІ ДО СТАТУТНОГО КАПІТАЛУ ГОСПОДАРСЬКИХ ТОВАРИСТВ
}

\begin{abstract}
ГЕРЦ Алла Анатоліївна - доктор юридичних наук, доцент кафедри цивільного права та процесу юридичного факультету Львівського національного університету імені Івана Франка

ТУРЧИН Лілія Ярославівна - магістр права, аспірантка кафедри цивільного права та процесу юридичного факультету Львівського національного університету імені Івана Франка
\end{abstract}

DOI:10.32782/NP.2019.4.18

У статті надано характеристику сутності статутного капіталу. Досліджено відмінності у використанні законодавцем термінологї для позначення майнової участі у статутному капіталі господарсъких товариств. На підставі такого дослідження сбормульовано висновок про доцільність вживання терміну «внесок». Вирізнено джерела формування статутного капіталу господарсъких товариств. Проілюстровано різні наукові позищй щодо внесення майнових прав інтелектуальної власності до статутного капіталу господарсъких товариств. Висловлено позицію щодо недоцільності обмеження можливості вносити майнові права інтелектуальної власності до статутного капіталу господарсъких товариств. Проаналізовано існуючі позицій науковиів щзодо виокремлення критерї̈в, яким повинні відповідати майнові внески до статутного капіталу господарсъких товариств та висловлено позицію щодо критеріӥв, яким повинні відповідати майнові права інтелектуальної власності для внесення їх до статутного капіталу господарсъких товариств. Охарактеризовано проблематику оцінювання майнових прав інтелектуальної власності з метою їх внесення до статутного капіталу господарсъких товариств.

Ключові слова: майнові права інтелектуальної власності, статутний капітал, господарсъкі товариства, грошова оцінка, внесок до статутного капіталу.
Актуальність теми дослідження

Можливість використання прав інтелектуальної власності як внеску до статутного капіталу господарських товариств є недостатньо врегульованим на законодавчому рівні. Таким чином, актуальними є дослідження механізму розпорядження майновими правами інтелектуальної власності, зокрема в частині внесення таких прав до статутного капіталу господарських товариств.

Виклад основного матеріалу статті

Метою створення господарських товариств $\epsilon$ їх участь в цивільному обороті. Оскільки такий має, здебільшого, майновий характер, то й важливе значення має те, яким майном володіють господарські товариства. Так, основним джерелом утворення майна господарських товариств $\epsilon$ статутний капітал.

Статутний капітал 6 не лише правовим поняттям, а й економічним. 3 економічної точки зору, статутний капітал розглядають як суму внесків власників підприємства в його активи за номінальною вартістю згідно із засновницькими документами [21, с. 103].

Статутний капітал господарських товариств формується за рахунок внесків (вкладів) учасників. При чому, законодавець не одностайний у використанні якогось конкретного терміну («вклад» чи «внесок»). Так, в положеннях Цивільного кодексу України для позначення майнової участі в статутному капіталі господарських товариств використовується лише термін «вклад». Вод- 
ночас положення Закону України «Про господарські товариства» та Господарського кодексу України містять обидва терміни. Згідно 3 частиною 4 статті 82 Господарського кодексу України статутом може бути встановлено порядок визначення розміру часток учасників залежно від зміни вартості майна, внесеного як вклад, та додаткових внесків учасників. 3 вказаного положення вбачається, що при первинному внесенні майна до статутного капіталу вживається термін «вклад», а при додатковому внесенні - «внесок». Водночас, згідно $з$ положенням статті 85 Господарського кодексу України господарське товариство $є$ власником майна, переданого йому у власність засновниками і учасниками як внески. Таким чином, деякі норми того ж Господарського кодексу України закріплюють термін «внесок» для позначення будь-якого передання майна у власність господарського товариства (як первинне внесення майна, так і додаткове).

Частиною 4 статті 10 Закону України «Про акціонерні товариства» закріплено положення, згідно з яким незатвердження установчими зборами статуту акціонерного товариства вважається відмовою засновників від створення цього товариства та є підставою для повернення засновникам внесків, зроблених ними в рахунок оплати акцій. Повернення внесків здійснюється протягом 20 робочих днів 3 дати проведення установчих зборів, на яких не було прийнято рішення про затвердження статуту акціонерного товариства. Положення частин 3 та 4 статті 15 вказаного Закону містять норми, відповідно до яких збільшення статутного капіталу акціонерного товариства із залученням додаткових внесків здійснюється шляхом розміщення додаткових акцій. Збільшення статутного капіталу акціонерного товариства без залучення додаткових внесків здійснюється шляхом підвищення номінальної вартості акцій. Термін «вклад» в цитованому Законі взагалі не використовується.

В свою чергу, Закон України «Про товариства 3 обмеженою та додатковою відповідальністю» містить лише термін «вклад» та не містить терміну «внесок». Зокрема, вкладом, відповідно до цього Закону, розуміють як первинне внесення майна до статутного капіталу, так і додаткове внесення (частина 3 статті 16 - «При збільшенні статутного капіталу за рахунок додаткових вкладів номінальна вартість частки учасника товариства може бути збільшена на суму, що дорівнює або менша за вартість додаткового вкладу такого учасника»), що суперечить термінології, вжитій у статті 82 Господарського кодексу України.

Податковий кодекс України у пункті 165.1.44 містить припис, згідно з яким до загального місячного (річного) оподатковуваного доходу платника податку не включається сума майнового та немайнового внеску платника податку до статутного капіталу юридичної особи - емітента корпоративних прав, в обмін на такі корпоративні права.

Зважаючи на таку неузгодженість положень законодавства, вважаємо за доцільне звернутись до філологічного підгрунтя обох термінів. Так, під вкладом в українській мові розуміють:

- грошову суму, внесену на збереження до ощадної каси або державного банку;

- що-небудь цінне внесене в громадську справу, науку, літературу і т. ін. [19].

Водночас, внеском є:

- гроші, які хтось сплачує організації, установі тощо;

- що-небудь цінне внесене в громадську справу, науку, літературу і т. ін. [19].

Згідно $з$ позицією науковців-філологів, слово «вклад» $е$ русизмом. Зокрема, М. Білоус та О. Сербенська радять замість словосполучення «вносити вклад» вживати словосполучення «зробити внесок». [7, с. 23].

В Юридичній енциклопедії [24] надано такі визначення досліджуваних термінів:

- вклади - це грошові суми або цінні папери, внесені юридичними чи фізичними особами для зберігання у кредитно-фінансові установи на певних умовах;

- внески - це майнова участь фізичної чи юридичної особи в заснуванні і здійсненні певного виду постійної чи тимчасової діяльності, зокрема діяльності політичних партій, профспілок, громадських і господарських організацій та їх об'єднань, релігійних організацій, окремих видів благодійної та іншої діяльності.

Зважаючи на всі вищезазначені аргументи, вважаємо за доцільне для позна- 


\section{Цивільне, підприсмницьке, господарське та трудове право}

чення майнової участі в статутному капіталі господарських товариств вживати термін «внесок». 3 приводу вказаного, доцільним є внесення відповідних змін до законодавства України (Цивільного кодексу України, Господарського кодексу України, Закону України «Про товариства з обмеженою та додатковою відповідальністю», Закону України «Про господарські товариства»).

Відповідно до положень частини 2 статті 115 Цивільного кодексу України внеском до статутного (складеного) капіталу господарського товариства можуть бути гроші, цінні папери, інші речі або майнові чи інші відчужувані права, що мають грошову оцінку, якщо інше не встановлено законом. Аналогічне положення є також в статті 13 Закону України «Про господарські товариства». Таким чином, цивільне законодавство передбачає можливість використання нематеріальних активів, при формуванні статутного капіталу господарських товариств. Зупинимось детальніше на майнових правах інтелектуальної власності як внесках до статутного капіталу господарських товариств.

Вважаємо, що для товариства негрошові внески (якими є й майнові права інтелектуальної власності) можуть бути досить привабливими. Зокрема, в окремих випадках, товариство навіть може бути більш зацікавлене в отриманні від учасника негрошового внеску, аніж грошового. Така ситуація має місце у випадку, коли відповідний внесок стосується речей або прав, які товариство змушене набути для свого ефективного функціонування.

Науковці, однак, по-різному ставляться до внесення негрошових активів до статутного капіталу. Так, А.Ф. Федоров, Г.Ф. Шершеневич свого часу виступали за можливість здійснення негрошових внесків, I.T. Тарасов заперечував проти цього, вважаючи, що внески можуть бути оплачувані лише грішми, на які можна придбати для товариства різного роду предмети відповідно до його цілей та потреб [23, с. 119].

Науковці В.В. Долинська, М.Г. Іонцев, I.B. Спасибо-Фатєєва, пропонують встановити співвідношення між грошовими і негрошовими внесками у статутному капіталі [12, с. 227], [13, с. 54.], [20, с. 241]; чи нада- ти можливість участі правами промислової власності в статутному капіталі акціонерного товариства, товариства 3 обмеженою відповідальністю і товариства з додатковою відповідальністю лише в частині, що перевищує законодавчо встановлений мінімальний розмір статутного капіталу, або, як пропонується Ю.С. Атамановою, повести загальну модифікацію конструкції статутного капіталу: поділити його на два фонди - фонд матеріальних активів і фонд нематеріальних активів [6, с. 190].

На нашу думку, потреби обмежувати можливість засновників (учасників) товариства вносити майнові права інтелектуальної власності до статутного капіталу господарських товариств немає. Адже ринок об'єктів права інтелектуальної власності в наш час активно розвивається, все частішими стають угоди з приводу відчуження та передачі у тимчасове користування майнових прав інтелектуальної власності, що свідчить про привабливість таких об'єктів для одержувачів прав на них. Більше того, лише для акціонерних товариств законодавство передбачає мінімальний розмір статутного капіталу. Щодо інших господарських товариств, то такі не обмежені у визначенні мінімального розміру свого статутного капіталу, а тому й будь-які обмеження щодо можливості внесення негрошових активів будуть невиправданими. Щодо можливості існування певних ризиків (пов'язаних $з$ оцінкою таких прав), то такі можливо усунути шляхом врегулювання процедури оцінки негрошових внесків.

Водночас, українське законодавство передбачає заборону формування статутного капіталу деяких видів господарських товариств за рахунок негрошових внесків. Це стосується фінансових установ, до яких належать банки, кредитні спілки, ломбарди, лізингові компанії, довірчі товариства, страхові компанії, установи накопичувального пенсійного забезпечення, інвестиційні фонди і компанії та інші юридичні особи, виключним видом діяльності яких є надання фінансових послуг, а у випадках, прямо визначених законом, - інші послуги (операціï), пов'язані з наданням фінансових послуг. 
В літературі по-різному розглядається питання стосовно того, що саме є об'єктом внеску до статутного капіталу. Деякі науковці таким вважають сам об'єкт права інтелектуальної власності [15], також трапляються думки стосовно того, що внеском є патент як охоронний документ [11] і навіть інтелектуальний капітал, під яким розуміються знання, що можуть бути перетворені на прибуток та оцінені [8] або ж - майнові права інтелектуальної власності [25], [18].

Стосовно вищезгаданого питання, підтримуємо останню позицію, згідно 3 якою об'єктом внеску до статутного капіталу виступають саме майнові права інтелектуальної власності, а не об'єкти права інтелектуальної власності чи охоронні документи. Вказана позиція узгоджується з виключним підходом та підтверджується українським законодавством. Зокрема, у статті 424 Цивільного кодексу України чітко зазначено, що саме майнові права інтелектуальної власності можуть бути внеском до статутного капіталу юридичних осіб. Положенням (стандартом) бухгалтерського обліку 8 «Нематеріальні активи», затвердженого наказом Miністерства фінансів України від 18.10.1999 p. № 242, як нематеріальні активи розглядаються саме права на відповідні об'єкти інтелектуальної власності, а не ці об’єкти як такі. Щодо охоронних документів, то, як слушно звернув увагу I.E. Якубівський, такі слід розглядати як документи, що засвідчують права, що вносяться до статутного капіталу. [25]

Слід зауважити, що подібне питання постає не лише в українській науці, але й закордонній, зокрема, європейській, також. Так, Я. Томкєвіч і Я. Блох називали свого часу внесками патенти, незапатентовані винаходи, авторські права [4, с. 24], А. Шуманьські - патент чи право на отримання патенту, а також майнові авторські права [3, с. 149-150], М. Мініас - права, що виникають 3 патенту, право на патент, майнові авторські права [2], П. Пініор - патент, право на патент, свідоцтво на знак для товарів і послуг, право на свідоцтво, ліцензія на використання винаходу чи корисної моделі, «ноу-хау», а також майнові авторські права [5, с. 119]. Слід уточнити, що польські нау- ковці розглядають патент як майнове право інтелектуальної власності (зокрема, промислової власності), що пояснює вищезазначені позиції науковців.

Виходячи 3 положень частини 2 статті 115 Цивільного кодексу України, законодавець чітко вимагає дотримання двох критеріїв, яким повинне відповідати майно як внесок до статутного капіталу: відчужуваність та можливість здійснення грошової оцінки.

Звертаючись до закордонного досвіду, корпоративне право Європейського союзу також містить спроби окреслення критеріїв спроможності негрошових внесків, зокрема, відповідне положення містить стаття 7 Директиви Свропейського Парламенту і Ради 2012/30/UE від 25.10.2012 про координацію гарантій, які вимагаються державами-членами від господарських товариств в розумінні пункту 2 статті 54 Трактату про функціонування Свропейського Союзу, з метою досягнення їх рівності, для охорони як інтересів учасників, так і третіх осіб в процесі створення акціонерного товариства, а також збереження та зміни його капіталу. Згідно 3 вищезазначеною статтею до складу статутного капіталу можуть входити лише активи, які можна оцінити.

Додатково звертаючись до юридичної наукової доктрини, О.А. Воловик обгрунтовує доцільність законодавчого забезпечення комплексу критеріїв, яким мають відповідати негрошові внески до статутного капіталу. До них науковець відносить ліквідність, адекватність оцінки внесків, потреба та можливість їх використання в господарській діяльності товариства [10, с. 7]. Водночас, вважаємо, що критерій можливості використання досліджуваних внесків у господарській діяльності товариства, якщо й слід брати до уваги, то лише в широкому розумінні. Адже у вузькому розумінні вказаний критерій невиправдано обмежує засновників (учасників, акціонерів) у свободі формування статутного капіталу. Зокрема, вид господарської діяльності товариства не обов'язково повинен співпадати зі сферою використання об'єкта інтелектуальної власності, права на який передаються до статутного капіталу. Припустимо, товари- 
ство може не використовувати об'єкт інтелектуальної власності у своєму виробництві, однак це не перешкоджає йому передавати відповідні права на об'єкт права інтелектуальної власності іншим особам за ліцензійним договором і отримувати від цього прибуток.

Загалом же ж, якщо абстрагуватися від вищенаведеного, то недоцільно виокремлювати критерій можливості використання майнових прав інтелектуальної власності, що передаються до статутного капіталу господарських товариств, у господарській діяльності такого товариства. Адже засновникам (учасникам, акціонерам) слід самостійно вирішувати питання необхідності (корисності, цінності тощо) товариству такого внеску.

Зокрема, на нашу думку, майнові права інтелектуальної власності як внески до статутного капіталу повинні відповідати лише таким критеріям як можливість здійснення грошової оцінки такого внеску; оборотоздатність (можливість вчиняти з ним правові дії на користь товариства).

Оцінка вартості прав на об'єкти права інтелектуальної власності відповідно до Міжнародних стандартів оцінки здійснюється, серед іншого, з метою визначення вартості інтелектуальної власності, що вноситься до статутного капіталу, вартості виключних прав, переданих на підставі договору про передачу прав на об'єкт інтелектуальної власності або ліцензійного договору на право використання такого об'єкта. [22, с. 306]

За своєю суттю об'єкти інтелектуальної власності нематеріальні, тому їх вартість, як i вартість майнових прав інтелектуальної власності не визначається традиційним способом, що використовується при оцінці матеріальних об'єктів.

Проблематика оцінювання об'єктів інтелектуальної власності полягає у такому: нематеріальність об'єктів інтелектуальної власності, через що застосування традиційних інструментів при визначенні їх вартості є неможливим; не всі інтелектуальні блага піддаються безпосередньому ринковому оцінюванню; у зв’язку з оригінальністю і неповторністю інтелектуальних продуктів та умов їх використання окремими суб'єктами господарювання не існує єдиної загальноприйнятої методики оцінювання об’єктів інтелектуальної власності; динаміка вартості інтелектуальної власності не завжди підпорядковується певній загальній закономірності, є індивідуальною для кожного конкретного її об'єкта, оскільки інновації не стільки йдуть за ринковою кон'юнктурою, скільки визначають їі зміни [14, с. 270].

Постановою Кабінету Міністрів України від 3 жовтня 2007 року № 1185 затверджено Національний стандарт № 4 «Оцінка майнових прав інтелектуальної власності». Національний стандарт № 4 є обов'язковим для застосування суб'єктами оціночної діяльності під час проведення оцінки майнових прав інтелектуальної власності, а також особами, які здійснюють відповідно до законодавства рецензування звітів про оцінку. Об'єктами оцінки відповідно до цього Стандарту є майнові права інтелектуальної власності, які належать до об'єктів у нематеріальній формі.

Відповідно до статті 9 Закону України «Про оцінку майна, майнових прав та професійну оціночну діяльність в Україні» та 3 урахуванням вимог Національного стандарту № 4 «Оцінка майнових прав інтелектуальної власності», затверджено Методику оцінки майнових прав інтелектуальної власності. Процедура оцінки майнових прав інтелектуальної власності включає послідовність дій, що визначені в розділі «Загальні вимоги до проведення незалежної оцінки майна» Національного стандарту № 1 «Загальні засади оцінки майна і майнових прав», затвердженого постановою Кабінету Міністрів України від 10.09.2003 № 1440.

Оцінка майнових прав інтелектуальної власності має важливе значення для забезпечення функцій статутного капіталу. Зокрема, у випадку неналежної оцінки відповідного внеску (оцінення внеску вище аніж його ринкова вартість), статутному капіталу як бухгалтерському запису на стороні пасивів, відповідатимуть на стороні активів внески нижчої вартості, що порушуватиме інтереси як самого товариства, так і його учасників та кредиторів.

Щодо критерію оборотоздатності, то такий передбачає, що в разі внесення до статутного капіталу майнових прав інтелекту- 
альної власності, такі мають бути предметом обороту і тільки в такому випадку можуть вноситись до статутного капіталу і становити актив товариства.

Деякі науковці окремо виділяють такий критерій як можливість входження внеску до ліквідаційної маси або до банкрутуючого товариства $[1$, с. 274]. Пропонований критерій походить з гарантійної функції статутного капіталу і забезпечує інтереси кредиторів товариства. Згідно з таким, предметом негрошового внеску може бути тільки таке право, з якого кредитори можуть задовольнити свої вимоги. Таке задоволення вимог виникає при банкрутстві і ліквідації товариства, оскільки до цього моменту товариство може використовувати інші ресурси для погашення своїх зобов'язань [5, с. 77]. Потрібно підкреслити, однак, що вказаний критерій є похідним від критеріїв оборотоздатності та можливості здійснення грошової оцінки, оскільки, у випадку, якщо майнове право може бути предметом цивільного обороту, піддається оцінці, то такий внесок може також збуватися в процесі банкрутства чи ліквідації товариства.

Повертаючись до грошової оцінки майнових прав інтелектуальної власності, слід зазначити, що така $є$ важливим етапом в процесі здійснення майнових прав інтелектуальної власності, зокрема, шляхом внесення до статутного капіталу. Розуміння підходів та методів оцінки дозволить правильно визначити вартість об'єктів права інтелектуальної власності для ефективного функціонування інтелектуальних активів в господарському обороті. [17, с.342]

Так, відповідно до положень статті 13 Закону України «Про господарські товариства» грошова оцінка внеску учасника господарського товариства здійснюється за згодою учасників товариства, а у випадках, встановлених законом, вона підлягає незалежній експертній оцінці.

Науковець В.М. Кравчук зазначає, що в цьому випадку потрібна згода всіх учасників, незалежно від розміру внеску, оскільки, законодавство вказує про згоду учасників (якщо оцінку дають учасники, то необхідна згода кожного 3 них), а не загальних зборів учасників товариства (якщо оцінку роблять загальні збори учасників, то рішення приймається більшістю голосів) [16]. Позиція науковця підтверджується положеннями частини 3 статті 13 Закону України «Про товариства з обмеженою та додатковою відповідальністю", які встановлюють, що внесок у негрошовій формі повинен мати грошову оцінку, що затверджується одностайним рішенням загальних зборів учасників, у яких взяли участь всі учасники товариства. При створенні товариства така оцінка визначається рішенням засновників про створення товариства.

Водночас, вважаємо положення статті 13 Закону України «Про товариства 3 обмеженою та додатковою відповідальністю» в частині затвердження грошової оцінки негрошового внеску одностайним рішенням загальних зборів учасників, у яких взяли участь всі учасники товариства дещо надмірними. Зокрема, на стадії створення товариства згода всіх засновників щодо грошової оцінки негрошового внеску є цілком виправдана, адже товариства як окремого суб'єкта ще не існує і всі дії, пов'язані з його створенням $\epsilon$ взаємним волевиявленням всіх засновників. Однак після створення товариства, таке виступає окремим суб'єктом цивільних правовідносин і дії від його імені вчиняються органами управління товариством. Щодо учасників, то такі $є$ членами загальних зборів як вищого органу товариства і саме через загальні збори можуть приймати рішення. Згідно з положеннями частини 2 статті 34 Закону України «Про товариства з обмеженою та додатковою відповідальністю» рішення про зміну розміру статутного капіталу товариства, приймаються трьома чвертями голосів усіх учасників товариства, які мають право голосу з відповідних питань. Зважаючи на вказане, оскільки зміна розміру статутного капіталу може відбуватись шляхом залучення нових учасників та здійснення ними внесків до статутного капіталу (в тому числі й негрошових), видається недоцільним встановлення необхідності одностайного рішення всіх учасників товариства для затвердження грошової оцінки негрошового внеску. Адже така норма може використовуватись учасниками товариства як спосіб зловживання своїми правами 


\section{Цивільне, підприсмницьке, господарське та трудове право}

(учасник, що хоче заблокувати процес передання негрошового внеску до статутного капіталу, не з'являтиметься чи не голосуватиме на загальних зборах, на яких затверджується грошова оцінка негрошового внеску).

Щодо акціонерних товариств, питання про затвердження оцінки майна, що вноситься засновниками в рахунок оплати акцій товариства вирішується на установчих зборах акціонерного товариства, де за нього повинні проголосувати всі засновники акціонерного товариства. Відповідно до частини 2 статті 11 вказаного Закону ціна майна, що вноситься засновниками акціонерного товариства в рахунок оплати акцій товариства, повинна відповідати ринковій вартості цього майна, визначеній відповідно до статті 8 цього Закону. Згідно з частиною 1 статті 8 Закону України «Про акціонерні товариства» ринкова вартість майна у разі його оцінки відповідно до цього Закону, інших актів законодавства або статуту акціонерного товариства визначається на засадах незалежної оцінки, проведеної відповідно до законодавства про оцінку майна, майнових прав та професійну оціночну діяльність. Рішення про залучення суб'єкта оціночної діяльності - суб'єкта господарювання приймається наглядовою радою товариства (у процесі створення товариства - зборами засновників або засновником особисто у разі створення акціонерного товариства однією особою). Зважаючи на вказані положення, при внесенні майна до статутного капіталу акціонерних товариств, обов'язковою $є$ незалежна оцінка такого майна суб'єктом оціночної діяльності. Рішення про залучення суб'єкта оціночної діяльності має прийматись або засновниками товариства, або установчі збори мають проводитися у два етапи, на першому 3 яких приймається рішення про залучення такого суб'єкта, а на другому - про затвердження проведеної ним оцінки майна [9, с. 44].

Стаття 7 Закону України «Про оцінку майна, майнових прав та професійну оціночну діяльність в Україні» передбачає обов'язкове проведення оцінки майна у випадках визначення вартості внесків учасників та засновників господарського товариства, якщо до зазначеного товари- ства вноситься майно господарських товариств 3 державною часткою (часткою комунального майна), а також у разі виходу (виключення) учасника або засновника із складу такого товариства. Окрім цього законодавством передбачено необхідність обов'язкової експертної оцінки іноземних інвестицій у вигляді будь-яких прав інтелектуальної власності. Зокрема, у статті 2 Закону України «Про режим іноземного інвестування» йдеться про те, що іноземні інвестиції можуть здійснюватися у вигляді будь-яких прав інтелектуальної власності, вартість яких у конвертованій валюті підтверджена згідно з законами (процедурами) країни інвестора або міжнародними торговельними звичаями, а також підтверджена експертною оцінкою в Україні, включаючи легалізовані на території України авторські права, права на винаходи, корисні моделі, промислові зразки, знаки для товарів і послуг, ноу-хау тощо. А положення статті 5 цього ж Закону передбачають, що іноземні інвестиції та інвестиції українських партнерів, включаючи внески до статутного капіталу підприємств, оцінюються в іноземній конвертованій валюті та у валюті України за домовленістю сторін на основі цін міжнародних ринків або ринку України.

На нашу думку, при внесенні майнових прав інтелектуальної власності до статутного капіталу, оцінка таких внесків суб'єктом оціночної діяльності має бути обов'язковою не лише для акціонерних товариств, господарських товариств 3 державною чи комунальною часткою чи у випадку здійснення іноземних інвестицій, але й загалом для господарських товариств. Незалежна оцінка сприятиме забезпеченню інтересів як учасників товариства, так і його кредиторів. Здійснювати оцінку негрошових внесків (зокрема, й майнових прав інтелектуальної власності) повинен суб'єкт оціночної діяльності. Така позиція обгрунтовується спеціальним статусом, яким наділений такий суб’єкт (професійна діяльність, державне регулювання, відповідальність тощо).

Досліджуючи можливість внесення майнових прав інтелектуальної власності до статутного капіталу господарських товариств, слід пам'ятати про обмеження таких прав 
щодо часу їх дії. Товариство, що отримало майнові права інтелектуальної власності як внесок до статутного капіталу, зможе ефективно користуватись такими правами протягом строку правової охорони відповідних прав. Водночас, незважаючи на закінчення відповідних строків, корпоративні права особи, яка здійснила відповідний внесок до статутного капіталу, залишаються за нею.

Підсумовуючи вищезазначене, майнові права інтелектуальної власності можуть бути досить привабливими для господарських товариств в якості внеску до статутного капіталу. При цьому, об'єктом внеску до статутного капіталу виступають саме майнові права інтелектуальної власності, а не об'єкти права інтелектуальної власності чи охоронні документи. При внесенні зазначених прав до статутного капіталу, такі повинні бути оборотоздатними та підлягати грошовій оцінці. Висловлено позицію щодо обов'язкового здійснення грошової оцінки майнових прав інтелектуальної власності суб'єктом оціночної діяльності при внесенні таких до статутного капіталу всіх видів господарських товариств.

\section{入iтepaтyрa}

1. Kodeks spółek handlowych. Warszawa: C.H. Beck, 2012. $1180 \mathrm{~s}$.

2. Minas M. Zdolność aportowa. Rejent. 1995. №9. S. 94.

3. Szumański A. Wkłady niepieniężne do spółek kapitałowych. Warszawa: Wydawnictwa Prawnicze Pwn, 1997. 350 s.

4. Tomkiewicz J. Kodeks handlowy. Spółka z ograniczoną odpowiedzialnością. Komentarz. Warszawa, 1934. 322 s.

5. Wkłady niepieniężne w spółkach handlowych/ W. Popiołka, P. Pinior, G. Gorczyński. Warszawa: LexisNexis, 2014. 507 S.

6. Атаманова Ю. Е. Участие в хозяйственных обществах правами промышленной собственности: правове проблемы передачи инновационного продукта. Право, 2004. С.196.

7. Білоус М. Екологія українського слова. Аьвів: Видавничий центр $\curlywedge$ НУ імені Івана Франка, 2005. 88 с.
8. Бутнік-Сіверський О. Б. Економіка інтелектуальної власності. Київ: ІнЮре, 2004. С. 514-540.

9. Вінник О.М. Науково-практичний коментар Закону України «Про акціонерні товариства». Юрінком Інтер, 2010. 312 с.

10. Воловик О.А. Господарсько-правове забезпечення корпоративних інтересів: автореф. дис. на здобуття наук. ступеня канд. юрид. наук. Донецьк, 2005. 20 с.

11. Городов О.А. Интеллектуальная собственность: правовые аспекты коммерческого использования: автореф. дис. на здобуття наук. ступеня докт. юр. наук. СанктПетербург. 1999. 33 с.

12. Долинская В.В. Акционерное право: основне положення и тенденции. Волтерс Клувер, 2006. С. 736.

13. Ионцев М.Г. Акционерные общества: Правовые основы имущественных отношений. Управление и контроль. Защита права акционеров. Ось-89, 2003. С. 416.

14. Інтелектуальна власність. В.П. Мартинюк, О.І. Вівчар, І.М. Вовна, Ю.С. Якубівська. Тернопіль: ТНЕУ, 2015. 360 с.

15. Клявлін В. Інтелектуальна власність у статутних фондах і балансах промислових підприємств. Інтелектуальна власність. 1999. №1. С. 35-40.

16. Кравчук В. М. Право інтелектуальної власності як вклад до статутного капіталу юридичної особи [Електронний ресурс]. 2014. Режим доступу до ресурсу: http://irbis-nbuv.gov.ua/cgi-bin/irbis_nbuv/ cgiirbis_64.exe? C21 COM $=2 \& \mathrm{I} 21 \overline{\mathrm{DBN}}=$ UJRN\&P $21 \mathrm{DBN}=\mathrm{UJRN} \& I M A G E \_F I L E$ DOWNLOAD $=1 \&$ Image_file_name $=$ PDF $/$ vnulpurn_2014_807_31.pdf.

17. Основні методичні підходи до оцінки ОПІВ інноваційного спрямування. Н. М. Столярчук. Економічні науки. Сер. Облік і фінанси. 2012. Вип. 9(3). С. 341-355.

18. Петренко В. С. Установчі договори щодо внесення майнових прав інтелектуальної власності в якості внесків до статутного фонду господарських товариств. Київ: Юрінком Інтер, 2019. С. 374-379.

19. Словник української мови [Електронний ресурс]. Академічний тлумачний словник. 1970. Режим доступу до ресурсу: http:// sum.in.ua/. 
20. Спасибо-Фатеева И.В. Акционерные общества: корпоративне правоотношения. Право, 1998. С. 256.

21.Терещенко О. О. Фінансова діяльність суб'єктів господарювання. Київ: КНЕУ, 2003. 554 c.

22. Управління інтелектуальною власністю. П.М. Цибульов, В.П. Чеботарьов, В. Г. Зінов, Ю. Суіні. Київ: «К.І.С.», 2005. 448 с.

23. Хорт Ю. В. Статутний капітал акціонерного товариства: захист інтересів учасників акціонерних правовідносин. Харків: Фінн, 2010. 276 с.

24. Юридична енциклопедія. Ю. С. Шемшученко, М. П. Зяблюк, В. П. Горбатенко та ін. Київ: Українська енциклопедія, 1998. $669 \mathrm{c}$.

25. Якубівський I. E. Правові засади внесення майнових прав інтелектуальної власності до статутного капіталу господарського товариства. Юридична Україна. 2009. №3. C. 58-63.
Turchyn L. Ya.

Some aspects of the transfer of intellectual property rights to the share capital of companies. - Article.

The article describes the nature of the share capital of companies. Differences in the use of terminology by the legislator to indicate property participation in the share capital of companies are investigated. On the basis of such research, the conclusion about the expediency of using the term contribution ("vnesok" in Ukrainian language) is formulated. The sources of formation of the share capital of the companies are distinguished. Different scientific positions on the transfer of intellectual property rights to the share capital of companies are illustrated. It was stated that it was inappropriate to limit the possibility of transferring intellectual property rights to the share capital of companies. The existing positions of the scientists on the identification of the criteria to be met by the property contributions to the share capital of the companies are analyzed. The authors proposed criteria to be met by the intellectual property rights for transferring them to the share capital of the companies. The problems of valuation of intellectual property rights with the purpose of their transfer to the share capital of companies are characterized.

Key words: intellectual property rights, share capital, companies, monetary valuation, contribution to the share capital. 